\section{Women for Oncology}

\author{
Padmaj Kulkarni ${ }^{1}$ Shruti Gandhi ${ }^{1}$ \\ ${ }^{1}$ Deenanath Mangeshkar Hospital and Research Center, Erandwane, \\ Pune, Maharashtra, India \\ Ind J Med Paediatr Oncol 2022;43:1-2.
}
यत्र नार्यस्तु पूज्यन्ते रमन्ते तत्र देवताः | यत्रैतास्तु न पूज्यन्ते सर्वास्तत्राफलाः क्रियाः ॥
The divine is extremely happy where women are respected; where they are not, all actions are fruitless.

Our descent from a land of Gargi and Maitreyi to a land of Nirbhaya has been quite spectacular. Centuries of foreign invasion and atrocities can be blamed, but only to a certain extent. Gender equality is not just about women's struggle, it is a story of upliftment of standards of humanity. A battery of reformers, men and women alike, have toiled hard and invested their blood and sweat so that women can reclaim their rightful position in society.

Female medical oncologists too are fighting their war for equality and have come together under the banner of "Women 4 Oncology (W4O)." Female oncologists have been inadequately represented in academia and clinical trials. As shown in a recent study, only $26 \%$ of 558 publications in two of the leading oncology journals of India had women lead authors. Only $32.7 \%$ of 324 respondents had a woman manager and men not only led $84.7 \%$ of male-majority teams but also $52.9 \%$ teams with gender equality and $26 \%$ teams with women majority. ${ }^{1}$

But, how do we change this situation? We need to work on some basic tenets of gender equality.

1. Recognition of uniqueness-Men and women, in addition to being equal, are unique. They have their own strengths and weaknesses. They complement each other and make a strong society. Women have been entrusted by nature the humongous responsibility of sustenance of humanity. A mother should never face the dilemma of whether to take care of her child or to go for work. Some societies have done well to provide maternal and paternal leaves, make creches available at workplace, provide convenient and flexible work schedules, provision of part time jobs, etc.
Address for correspondence Padmaj Kulkarni, MD, DM, Deenanath Mangeshkar Hospital and Research Center, Deenanath Mangeshkar Hospital Road, Near Mhatre Bridge, Erandwane, Pune, Maharashtra 411004, India (e-mail: editorijmpo@gmail.com).

2. Equality of freedom-Freedom constitutes a fundamental right as enshrined in Article 19 of the Indian Constitution. Men and women should have equal freedom to exercise their choices and this training should start right from childhood. The shackles of stereotypical gender appropriate behavior can then be broken easily leading the path to a truly modern society. Freedom to choose one's profession and pay parity should be integral part of this freedom.

3. Equality of opportunities-Hard work, sincerity, intelligence, skill, merit, and other similar virtues should form the basis of getting opportunities. Job opportunities as well as leadership positions should be equally available to all, irrespective of their gender.

4. Mutual trust and respect-These are the basis of any civilized society and lead to voluntary gender appropriate behavior.

The fearless and sustained struggle by countless women all over the globe has certainly helped, and we have made some progress in the field of female empowerment. Recent trends show some improvement in the number of women in medical oncology and many women do hold key positions in academics as well as clinical practice. These female leaders will be seen as role model for young women medical oncologists.

Indian Journal of Medical and Pediatric Oncology (IJMPO) has taken a lead in this domain by bringing a W4O issue. It has been prepared by a team of women oncologists led by my colleague and friend Dr. Jyoti Bajpai. All the articles published in this issue have women as first and/or corresponding authors. It is our effort to acknowledge the plight and struggle of women oncologists, recognize their strength, and provide them due recognition. It also has been our endeavor to provide appropriate gender-neutral representation in our Editorial Board. We are sure to have even more active involvement of women in the functioning of IJMPO. As
DOI https://doi.org/ 10.1055/s-0042-1743194. ISSN 0971-5851. (c) 2022. Indian Society of Medical and Paediatric Oncology. All rights reserved.

This is an open access article published by Thieme under the terms of the Creative Commons Attribution-NonDerivative-NonCommercial-License, permitting copying and reproduction so long as the original work is given appropriate credit. Contents may not be used for commercial purposes, or adapted, remixed, transformed or built upon. (https://creativecommons.org/ licenses/by-nc-nd/4.0/)

Thieme Medical and Scientific Publishers Pvt. Ltd., A-12, 2nd Floor, Sector 2, Noida-201301 UP, India 


\section{From the Editor-in-Chief}

they rightly say, "Be the change you wish to see!" We firmly believe that all these steps, however small, do matter and shall lead us to a fair, equal, and truly free world.

In Maya Angelou's words

"We have lived a painful history,

We know the shameful past,

But I keep on marching forward,
And you keep on coming last.

Equality, and I will be free

Equality, and I will be free."

\section{References}

1 Bajpai J, Mailankody S, Nair R, et al. Gender climate in Indian oncology: national survey report. ESMO Open 2020;5(02): e000671 